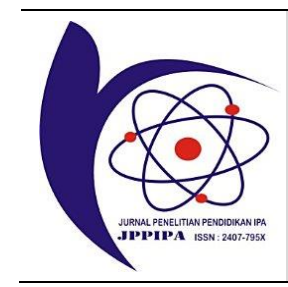

\title{
Cross-Section Resistivity Detection of Tree (Swietenia Magahoni and Gmelina) Using ERT Method
}

\author{
Evi Fazriati ${ }^{1}$, Asep Purnama1, Gian Agistian Algifari1, Irene Siti Amilah Muslimah'1, Fitria Hapsari \\ Puteri Sumanto ${ }^{1}$, Kartika Hajar Kirana ${ }^{1,2^{*}}$, Kusnahadi Susanto ${ }^{1}$ \\ ${ }^{1}$ Department of Geophysics, Faculty of Mathematics and Natural Sciences, Universitas Padjadjaran, Bandung, Indonesia \\ ${ }^{2}$ Citarum Centre of Research, Universitas Padjadjaran, Bandung, Indonesia
}

DOI: $\underline{10.29303 / \text { ippipa.v8i1.965 }}$

\section{Article Info}

Received: September 15, 2021

Revised: December 23, 2021

Accepted: December 25, 2021

Published: January 31, 2022

\begin{abstract}
The existence of trees is very beneficial for humans' life. There are utilizations of tree such as urban planning and reforestation. However, the tree can be dangerous when the tree is aged and decay because of several factors that might because fallen tree. Furthermore, monitoring activity is needed to know the condition of the tree. One of the methods that can be used to detect hollows in the living tree is Electrical Resistivity Tomography (ERT). The ERT is an efficient and non-destructive method that can be potential to estimate resistivity cross-section. The measurement of ERT was conducted on Swietenia mahagoni and Gmelina with unhealthy and healthy conditions visually. The data was processed using Res2Dinv and reconstructed for obtaining 2D resistivity cross-section. The results show that the unhealthy Swietenia mahagoni has logarithmic resistivity value range between 0.1-1 $\Omega \mathrm{m}$ and the healthy Swietenia mahagoni has $1-4 \Omega \mathrm{m}$. Meanwhile, the unhealthy and healthy Gmelina has a logarithmic resistivity value range between 0.5-4.5 $\Omega \mathrm{m}$ and $0.5-3 \Omega \mathrm{m}$, respectively. It is shown that the tree indicated health visually from a biological view does not mean the tree is in decay. It might be influenced by the phenology factor and/or the species of the tree.
\end{abstract}

Keywords: Tree; Resistivity; Electrical Resistivity Tomography; Swietenia mahagoni; Gmelina

Citation: Fazriati, E., Purnama, A., Algifari, G.A., Muslimah, I.S.A., Sumanto, F.H.P., Kirana, K.H., \& Susanto, K. (2022). Cross-Section Resistivity Detection of Tree (Swietenia Magahoni and Gmelina) Using ERT Method. Jurnal Penelitian Pendidikan IPA, 8(1), 39-44. https://doi.org/10.29303/jppipa.v8i1.965

\section{Introduction}

Trees have many benefits for humans and the environment. This is because trees can produce oxygen for a living (Nurnovita, 2011). Furthermore, trees are able to reduce air pollution, because, through their leaves, trees can catch lead particles derived from vehicles (Hendrasarie, 2007). The decay of trees often leads to personal injury or property damage on both private and public land, and trees are regularly cut because they are considered an unacceptable risk and/or a legal liability. Therefore, to mitigate the decay of trees, monitoring of growth and health of the tree is needed with a proper method. The electrical Resistivity Tomography (ERT) method can be used to detect tree decay (Larsson, et al., 2004; Soge, et al., 2018).
The ERT is one of the resistivity methods that can be carried out in a relatively fast and non-destructive that is very potential in estimating the subsurface crosssectional structure (Santoso, 2016). Usually, this method can be used to determine subsurface resistivity patterns in the investigation of rock types (Setiadi, et al., 2016), identification of groundwater (Santoso, et al., 2018), distribution of pollution (Kirana, et al., 2015), identification distribution of plant roots (Nazari et al., 2015). The resulting resistivity value distribution pattern will show the physical properties of a medium when an electric current is injected. A conductive material, such as water, will produce a low resistivity value, while a non-conducting material, such as air, will produce a large resistivity value because electric current is difficult to flow. In the last decade, the

\footnotetext{
*Email: kartika@geophys.unpad.ac.id
} 
development of the ERT method was also carried out to measure water content in tree trunks and structural differentiation in tree trunks (Lin, et al, 2012; Guyot, et al, 2013) as well as identification of tree decay (Larsson et al., 2004; Soge, et al., 2018).

The identification of tree cross-sections using the ERT method assumes that unhealthy trees will have hollow and filled with air. This will cause an anomaly in the measured resistivity compared to healthy trees. The research of Guyot, et al. (2013) showed that the deeper the tree, the higher the resistivity value. Guyot et al. (2013) and Lin et al. (2012) used the electrodes that have been synchronized with Picus Software in detecting tree structures. However, that study still needs improvement in inversion resolution. Moreover, to detect the tree cross-section, not all regions have the tool to monitor tree conditions. A modest method is needed that can utilize components easily obtained but consistently identify the physical properties of trees through ERT.

Therefore, the purpose of this study was to detect tree cross-section through the ERT method to determine the cross-section of resistivity values for unhealthy and healthy trees visually from biological review, then it can be used in monitoring the tree health from an early age and can reduce the risk of falling trees.

\section{Method}

The principle of the resistivity method is the injection of an electric current into the ground through two electrodes of current accompanied by two potential electrodes (Telford, et al., 1990; Reynolds, 2011). The measured values of current and electric potential are used to calculate the apparent resistivity of a medium. The apparent resistivity value is an intrinsic property of the material related to the ability of the medium to conduct electric current.

The cross-sectional image of the measurement using the resistivity method can be conducted in several ways, one of those is ERT. Guyot, et al (2013) performed the ERT method using a dipole-dipole configuration. However, this study will use the Wenner configuration. This is due to the Wenner configuration can produce a low error value (Noor, et al., 2020) and the inversion results have a lateral advantage.

The Wenner configuration is a configuration with the same length in distance between the electrodes. The distance between the current electrodes $\left(C_{1}\right.$ and $\left.C_{2}\right)$ is three times to the distance between the potential electrodes $\left(\mathrm{P}_{1}\right.$ and $\left.\mathrm{P}_{2}\right)$ as shown in Figure 1.
C: Current electrode

P: Potential electrode a: Space between each electrode

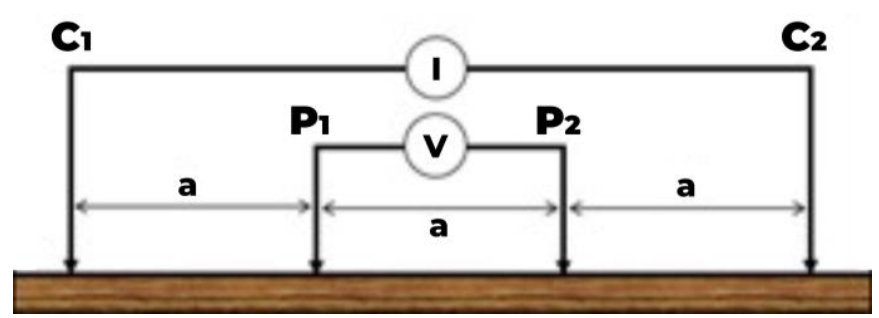

Figure 1. Wenner Configuration of Electrode

In this study, the acquisition process uses some equipment: an accumulator as current sources, 2 digital multimeters as current and potential meter devices, 31 tiny electrodes of length $40 \mathrm{~mm}$, and some cables as current connectors. Figure 2 shows an illustration of the arrangement of equipment in the measurement process.

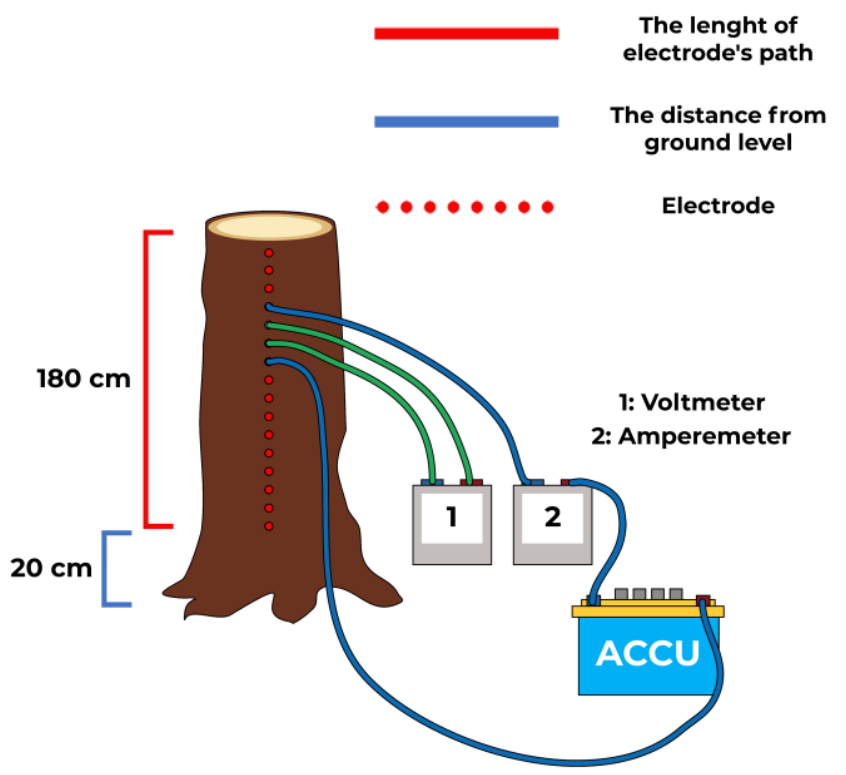

Figure 2. Illustration of Acquisition Design Survey

Measurements were made on two tree species, Swietenia mahagoni and Gmelina with various circumferences from $597 \mathrm{~mm}$ to $910 \mathrm{~mm}$. Trees have a biological visual condition that is unhealthy and healthy. Trees with unhealthy visual conditions are characterized by tree trunks infested with termites, peeling tree bark, and fallen leaves. While the condition of the tree that is visually healthy shows the opposite condition. Four trees are measured. The ERT acquisition on each tree was carried out in 2 vertical lines following the tree trunk. Then, the total number of lines in all trees is eight. The measurement data consist of the electric current (I) and potential difference $(\mathrm{V})$. Furthermore, the apparent resistivity value $\left(\rho_{a}\right)$ was calculated by: 


$$
\rho \mathrm{a}=\mathrm{k} \frac{\Delta \mathrm{V}}{I}
$$

Afterward, the 2-dimensional inversion process is carried out using Res2Dinv software to get the actual resistivity value range of the resulting cross-section.

\section{Result and Discussion}

The result of resistivity value cross for each tree is shown in Figures 3-6. The resistivity value of indicated unhealthy Swietenia mahagoni tree has ranged between $0.02-16.9 \Omega \mathrm{m}$ and shows an irregular cross- section (Figure 3), whereas the Swietenia mahagoni that indicated health shows a regular cross-section (Figure 4) with resistivity value between 0.09-341 $\Omega \mathrm{m}$.

Meanwhile, resistivity value cross-section of Gmelina that indicated unhealthy shows differences between lines. The appearance cross-section of line 1 has a regular pattern and line 2 is an irregular pattern (Figure 5) with a range of resistivity value between 0.17-9.44 $\Omega \mathrm{m}$. The Gmelina that indicated health has a range of resistivity value $0.101-1.54 \Omega \mathrm{m}$ with the regular pattern shown by the cross-section, both in line 1 and line 2 (Figure 6).

Resistivity Cross Section of Unhealthy Swietenia Mahagoni (Line 1)

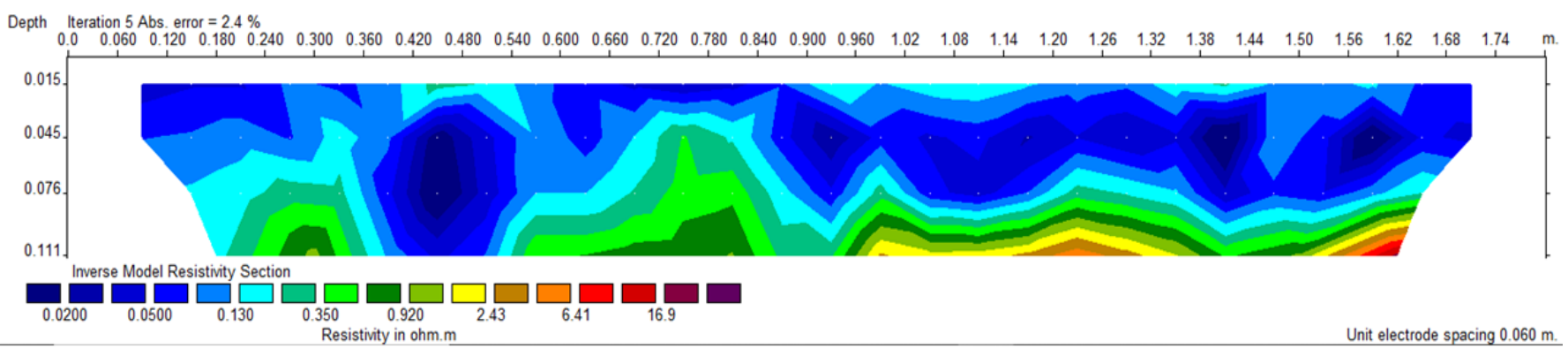

(a)

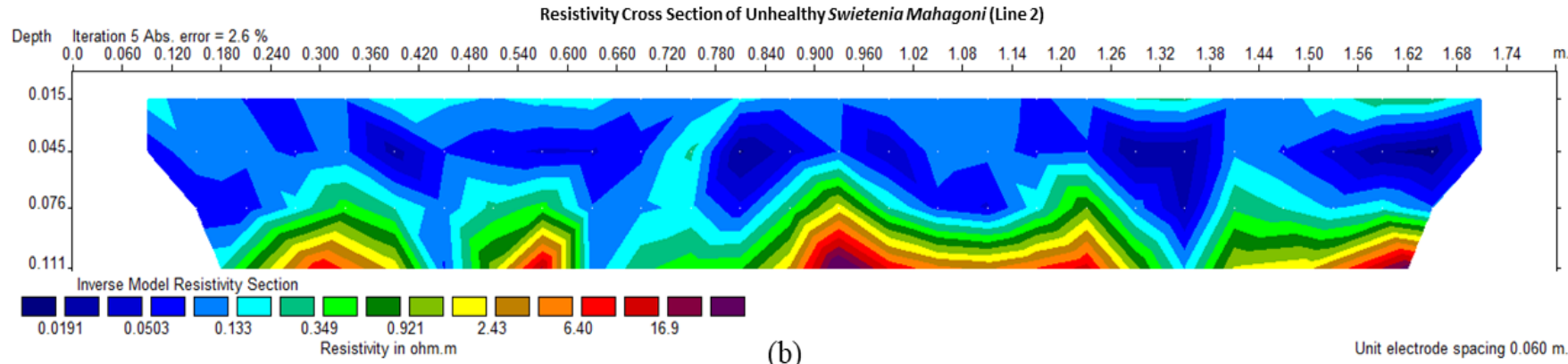

Figure 3. Resistivity Cross-section of Swietenia mahagoni with Unhealthy Condition from (a) Line 1 (b) Line 2

Based on the results of resistivity value range from all trees that indicated unhealthy and healthy, the health Swietenia mahagoni has higher resistivity value rather than the unhealthy, while the health Gmelina has lower resistivity value rather than the unhealthy. These results are quite similar to the research conducted by Luo et al. (2020) with a different type of tree (Allocasuarina verticillate). The range of resistivity values from the study of Luo et al. (2020) is around 65.21-89.46 $\Omega \mathrm{m}$.

Further analysis is necessary to obtain unhealthy and healthy tree either Swietenia mahagoni or Gmelina. Each line of resistivity cross-section is reconstructed for each tree sample. Reconstruction was conducted with a logarithmic scale to equalize the resistivity value for each tree. The resistivity value result is based on the reconstruction shown in Figures 7 and 8 .

The result of cross-section reconstruction for Swietenia mahagoni shows the contrast result between unhealthy and healthy tree observed from resistivity value and cross-section. The unhealthy tree has a low resistivity value range between $0.1-1 \Omega \mathrm{m}$ and indecisive cross-section, whereas the healthy has a high resistivity value range between 1-4 $\Omega \mathrm{m}$ and decisive cross-section. Dissimilar results are shown in reconstruction results for Gmelina that seen in Table 1. 
Resistivity Cross Section of Healthy Swietenia Mahagoni (Line 1)

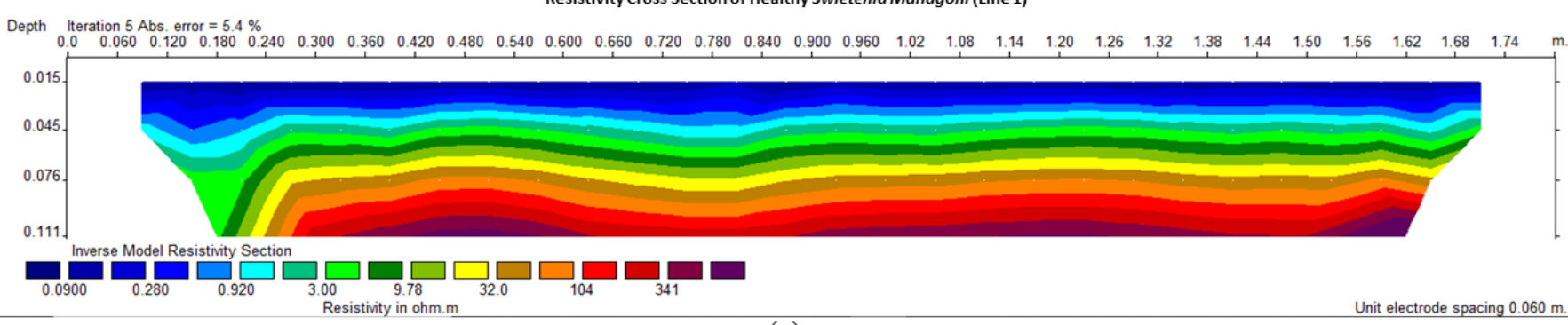

(a)

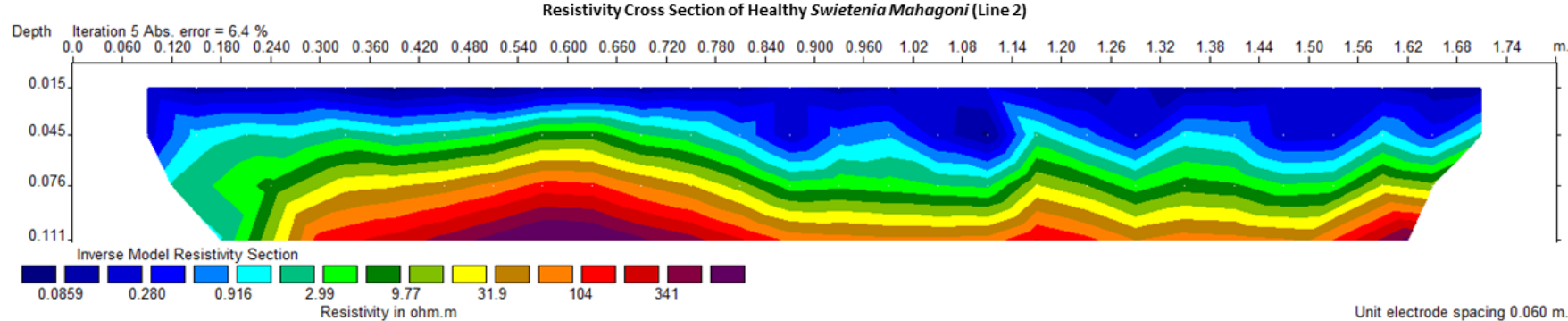

(b)

Figure 4. Resistivity Cross-section of Swietenia mahagoni with Healthy Condition from (a) Line 1 (b) Line 2

Resistivity Cross Section of Healthy Gmelina (Line 1)

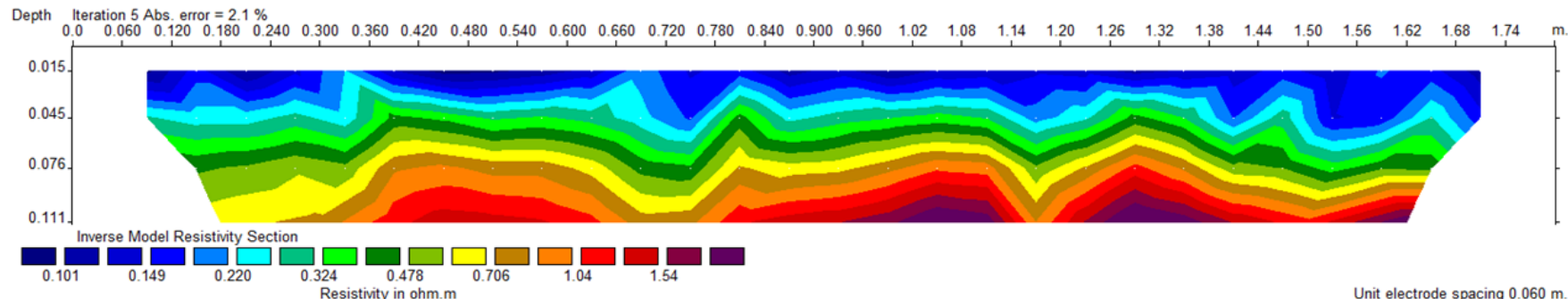

(a)

Resistivity Cross Section of Healthy Gmelina (Line 2)

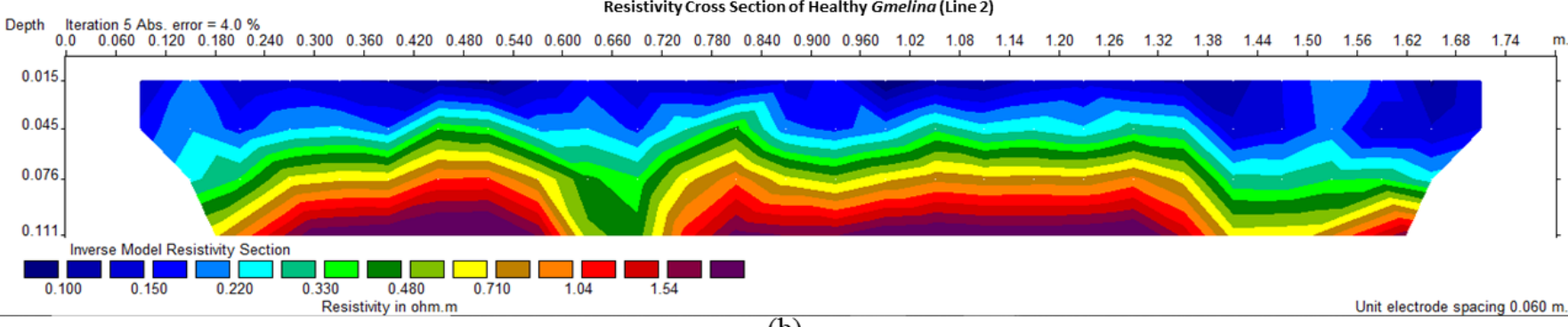

Figure 5. Resistivity Cross Section of Gmelina with Unhealthy Condition From (a) Line 1 (b) Line 2

Tabel 1. Tree resistivity value generated from reconstructed in logarithmic scale

\begin{tabular}{llll}
\hline Type & Condition & $\begin{array}{l}\text { Circumferences } \\
(\mathrm{mm})\end{array}$ & $\begin{array}{l}\text { Resistivity } \\
\text { value }(\Omega \mathrm{m})\end{array}$ \\
\hline $\begin{array}{l}\text { Swietenia } \\
\text { Mahagoni }\end{array}$ & Unhealthy & 910 & $0.1-1$ \\
& Healthy & 620 & $1-4$ \\
Gmelina & Unhealthy & 660 & $0.5-4.5$ \\
& Healthy & 597 & $0.5-3$ \\
\hline
\end{tabular}

According to Johnstone, et al. (2010), the decay tree trunk will have a low relative resistivity value rather than the tree trunk with a health condition, it might be caused by the increase of cation concentration at the wood. However, if we consider the results of this research with a previous study, only Swietenia mahagoni meet the reference. Meanwhile, either resistivity value or cross-section of Gmelina tree is opposite to the reference. The inappropriate result of Gmelina is due to species of the tree or phenology factors. The phenology factor is a tree cycle effect by environmental conditions and plants' biological phases, such as flowering, leaf discoloration, and leaf fall (Cleland, et al., 2012). Other 
than that, the difficulty of resistivity tomography interpretation might be another factor in analysis both

of unhealthy and healthy trees (Johnstone, et al., 2010).

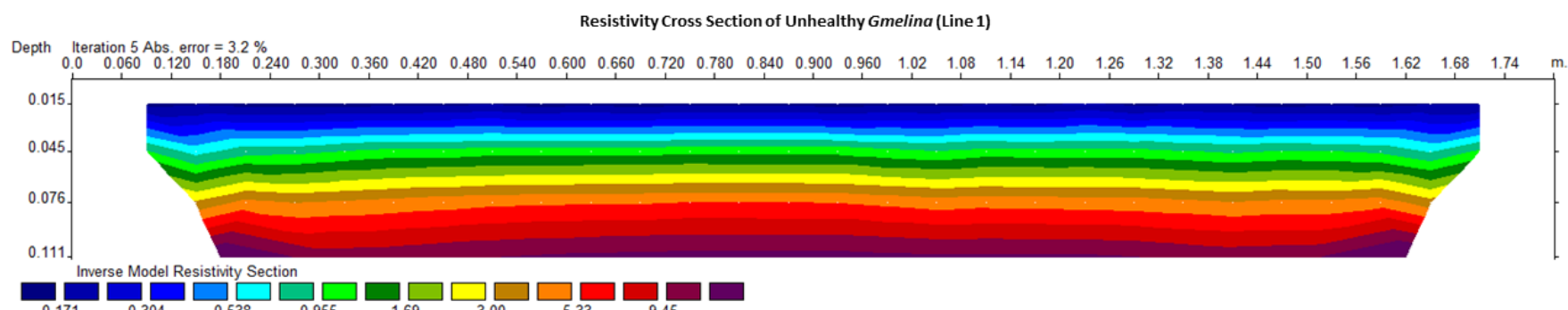

(a)

Unit electrode spacing $0.060 \mathrm{~m}$

Resistivity Cross Section of Unhealthy Gmelina (Line 2)

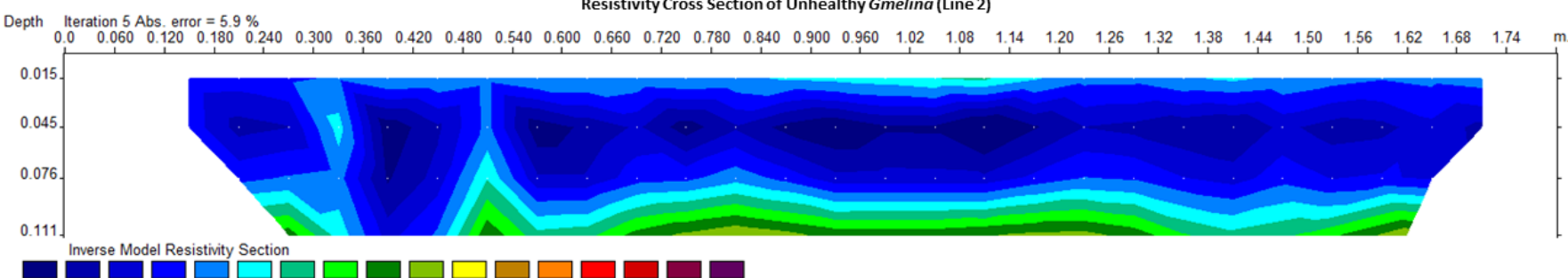

(b)

Unit electrode spacing $0.060 \mathrm{~m}$

Figure 6. Resistivity Cross-section of Gmelina with Healthy Condition from (a) Line 1 (b) Line 2

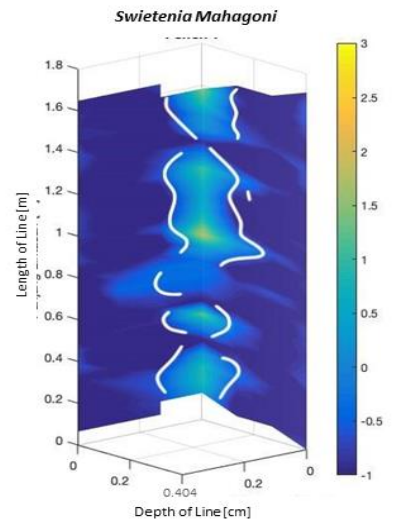

(a)

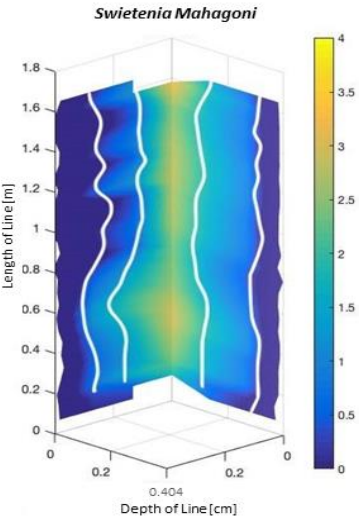

(b)

Figure 7. Swietenia mahagoni cross-section after reconstruction (a) unhealthy (b) healthy

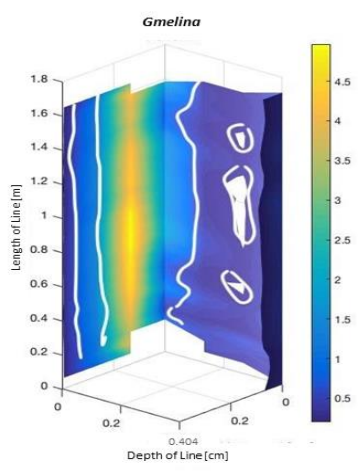

(c)

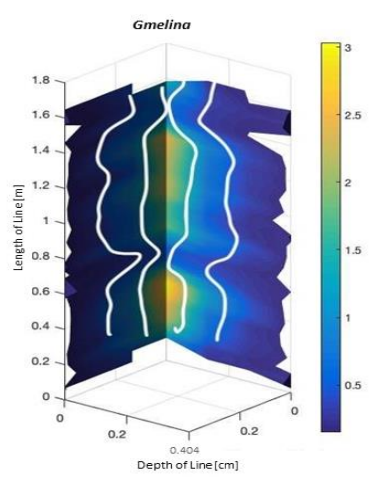

(d)

Figure 8. Gmelina cross-section after Reconstruction (a) Unhealthy (b) Healthy

\section{Conclusion}

The unhealthy Swietenia mahagoni has a logarithmic resistivity value range between $0.1-1 \Omega \mathrm{m}$ and the healthy is 1-4 $\Omega \mathrm{m}$. Meanwhile, the unhealthy and healthy Gmelina has a logarithmic resistivity value range between $0.5-4.5 \Omega \mathrm{m}$ and $0.5-3 \Omega \mathrm{m}$, respectively. It shows that the tree indicated health visually from biological review does not mean the tree is decaying. It might be influenced by phenology factors and/or species of the tree.

\section{Acknowledgments}

Thank you to the Ministry of Education, Culture, Research, and Technology for providing financial support to conduct research throughout the PKM with contract number 1949/E2/KM.05.01/2021. We also thank to Dr. Irwan Ary Dharmawan Kusnahadi Susanto, M.T., and Dr. Teguh Husodo for non-financial support.

\section{References}

Guyot, A., Ostergaard, K.T., Lenkopane, M., Fan, J., \& Lockington, D.A. (2013). Using electrical resistivity tomography to differentiate sapwood from heartwood: application to conifers. Tree physiology, 33(2), 187-194. https://doi.org/10.1093/treephys/tps128 
Hendrasarie, N. (2007). Kajian Efektivitas Tanaman Dalam Menjerap Kandungan $\mathrm{Pb}$ di Udara. Jurnal Rekayasa Perencanaan. 3(2). 1-15. Retrieved from: https://core.ac.uk/download/pdf/12216725.pdf

Johnstone, D., Moore, G., Tausz, M., \& Nicolas, M. (2010). The Measurement of Wood Decay in Landscape Trees. Arboriculture and Urban Forestry, 36, 121-127. https://doi.org/10.48044/jauf.2010.016.

Kirana, K. H., Susanto, K., \& Susilawati, A. (2015). Subsurface investigation in Sarimukti landfill using DC resistivity. AIP Conference Proceedings, 1677(1), 60020. https://doi.org/10.1063/1.4930700.

Larsson, B., Bengtsson, B., \& Gustafsson, M. (2004). Nondestructive detection of decay in living trees. Tree Physiology, 24(7), 853-858. https://doi.org/10.1093/treephys/24.7.853

Lin, C.-J., Chung, C.-H., Yang, T.-H., \& Lin, F.-C. (2012). Detection of Electric Resistivity Tomography and Evaluation of the Sapwood-Heartwood Demarcation in Three Asia Gymnosperm Species. Silva Fennica, 46(3), 415-424 https://doi.org/10.14214/sf.440

Luo, Z., Deng, Z., Singha, K., Zhang, X., Liu, N., Zhou, Y., \& Guan, H. (2020). Temporal and spatial variation in water content within living tree stems determined by electrical resistivity tomography. Agricultural and Forest Meteorology, 291, 108058. https://doi.org/10.1016/j.agrformet.2020.108058

Nazari, Y. A., Fakhrurrazie, F., Aidawati, N., \& Gunawan, G. (2015). Deteksi Perakaran Kelapa Sawit Pada Lubang Biopori Modifikasi Dengan Metode Geolistrik Resistivitas. Ziraa'ah Majalah Ilmiah Pertanian, 40(1), 31-39. http://dx.doi.org/10.31602/zmip.v40i1.95

Noor, R. H., Ishaq, I., Jarwanto, J., \& Priono, D. (2020). Eksplorasi Akuifer Air Bawah Tanah Menggunakan Metode Tahanan Jenis 2d Di Desa Selaru Kabupaten Kotabaru, Kalimantan Selatan. Al Ulum Jurnal Sains Dan Teknologi, 5(2), 74-82. http://dx.doi.org/10.31602/ajst.v5i2.2886

Nurnovita, C. (2019). Evaluasi Fungsi Ekologis Pohon Pada Rth Lanskap Permukiman Sentul City, Bogor (Studi Kasus: Cluster Bukit Golf Hijau). https://doi.org/10.31237/osf.io/546ts

Reynolds, J.M. (2011). An introduction to applied and environmental geophysics. John Wiley \& Sons.

Santoso, B., Setianto, R., \& Mohammad, I.H. (2018). Investigasi Gerakan Tanah dan Akuifer Menggunakan Metode Electrical Resistivity Tomography di Sekitar Lereng BGG Jatinangor. JIIF (Jurnal Ilmu dan Inovasi Fisika), 2(1), 45-52. https://doi.org/10.24198/jiif.v2i1.15392
Santoso, B., Wijatmoko, B., Supriyana, E., \& Harja, A. (2016). Penentuan resistivitas batubara menggunakan metode electrical resistivity tomography dan vertical electrical sounding. Jurnal Material dan Energi Indonesia, 6(01), 8-14. https://doi.org/10.24198/imei.v6i01.9371

Setiadi, M., \& Sampurno, J. (2016). Identifikasi sebaran batuan beku di bukit koci desa Sempalai Kabupaten Sambas Kalimantan Barat dengan menggunakan metode geolistrik resistivitas. Positron, 6(2), 53-59. http://dx.doi.org/10.26418/positron.v6i2.16879

Soge, A., Popoola, O., \& Adetoyinbo, A. (2018). Detection of decay and hollows in living almond trees (Terminalia catappa L. Roxb.) using electrical resistivity method. Journal of the Indian Academy of Wood Science, 15(2), 181-189. https://doi.org/10.1007/s13196-018-0224-3

Telford, W. M., Telford, W. M., Geldart, L. P., \& Sheriff, R. E. (1990). Applied geophysics. Cambridge university press.

Telford, W.M., Geldart, L.P. \& Sheriff, R.E. (2004). Applied Geophysics (2nd edition). London: Cambridge University Press. 